\title{
Divíme se
}

\section{Jiří Nečas}

Envigogika 11 (2) - Inspirace / Inspiration

Published/ Publikováno 28. 12. 2016

DOI : $10.14712 / 18023061.537$

\begin{abstract}
Abstrakt
Ve své promluvě k věříím autor připomíná text ze 17. kapitoly Skutků, pojednávající o Pavlově kázání v Aténách. Pavel je zkušeným kazatelem a chce své posluchače převést $\mathrm{k}$ Bohu - v návaznosti na jejich dosavadní názory a původní náboženské myšlení. Jeho postup je promyšlený, a je dokonce $v$ souladu $s$ dnešními didaktickými představami; těch, kdo se při této př́ležitosti obrátili ke Kristu, bylo však relativně málo. Někdo $v$ tom může vidět $i$ určité kazatelské fiasko, ovšem biblicky utvářenému způsobu myšlení se příći jakékoli pomyšlení na efektivitu zvěstování.
\end{abstract}

\section{Klíčová slova}

kázání, apoštol Pavel

\begin{abstract}
The author, in his address to the faithful recalls the text of chapter 17 of the Acts of the Apostles, in Paul's preaching in Athens. Paul is an experienced preacher and wants his listeners to convert to Christianity - based on their existing worldviews and original religious thinking. His method is ingenious, and is even in line with today's didactic techniques; the number of those who converted to Christ on this occasion, however, was relatively low. Some in fact may even consider this to be a preaching fiasco, but a religious way of thinking excludes consideration of the effectiveness of the prostelatization.
\end{abstract}

\section{Key words}

preaching; apostle Paul 


\section{Žalm 8}

2 Hospodine, Pane náš, jak vznešené je tvoje jméno po vší zemi! Svou velebnost vyvýšil jsi nad nebesa.

4 Vidím tvá nebesa, dílo tvých prstů, měsíc a hvězdy, jež jsi tam upevnil:

5 Co je člověk, že na něho pamatuješ, syn člověka, že se ho ujímáš?

6 Jen maličko jsi ho omezil, že není roven Bohu, korunuješ ho slávou a důstojností.

7 Svěřuješ mu vládu nad dílem svých rukou, všechno pod nohy mu kladeš.

10 Hospodine, Pane náš, jak vznešené je tvoje jméno po vší zemi!

\section{Skutky 17}

22 Pavel se tedy postavil doprostřed shromáždění na Areopagu a promluvil: "Athéňané, vidím, že jste v uctívání bohů velice horliví.

23 Když jsem procházel vašimi posvátnými místy a prohlížel si je, nalezl jsem i oltář s nápisem: 'Neznámému bohu'. Koho takto uctíváte, a ještě neznáte, toho vám zvěstuji:

24 Bůh, který učinil svět a všechno, co je v něm, ten je pánem nebe i země, a nebydlí v chrámech, které lidé vystavěli,

25 ani si nedává od lidí sloužit, jako by byl na nich závislý; vždyt' je to on sám, který všemu dává život, dech i všechno ostatní.

26 On stvořil z jednoho člověka všechno lidstvo, aby přebývalo na povrchu země, určil pevná roční údobí i hranice lidských sídel.

27 Bůh to učinil proto, aby ho lidé hledali, zda by se ho snad nějakým způsobem mohli dopátrat a tak ho nalézt, a přece není od nikoho z nás daleko.

28 'Nebot' v něm žijeme, pohybujeme se, jsme', jak to říkají i někteří z vašich básníků: 'Vždyt' jsme jeho děti.

29 J sme-li tedy Božími dětmi, nemůžeme si myslet, že božstvo se podobá něčemu, co bylo vyrobeno ze zlata, stř́bra nebo z kamene lidskou zručností a důmyslem.

30 Bůh však prominul lidem dobu, kdy to ještě nemohli pochopit, a nyní zvěstuje všem, at' jsou kdekoliv, aby této neznalosti litovali a obrátili se k němu.

31 Nebot́ ustanovil den, v němž bude spravedlivě soudit celý svět skrze muže, kterého $k$ tomu určil. Všem lidem o tom poskytl důkaz, když jej vzkřísil z mrtvých."

32 Jakmile uslyšeli o vzkř́šení z mrtvých, jedni se mu začali smát a druzí řekli: "Rádi si tě poslechneme, ale až někdy jindy."

33 A tak Pavel od nich odešel.

34 Někteří se však k němu připojili a uvěřili; mezi nimi byl i Dionysios z Areopagu, žena jménem Damaris a s nimi ještě jiní. 


\section{Jan 10 (slova Pána J ežíše Krista)}

11 Já jsem dobrý pastýř. Dobrý pastýř položí svůj život za ovce.

12 Ten, kdo není pastýŕ, kdo pracuje jen za mzdu a ovce nejsou jeho vlastní, opouští je a utíká, když vidí, že se blíži vlk. A vlk ovce trhá a rozhání.

13 Tomu, kdo je najat za mzdu, na nich nezáleží.

14 Já jsem dobrý pastýř; znám své ovce a ony znají mne,

15 tak jako mě zná Otec a já znám Otce. A svůj život dávám za ovce.

16 Mám i jiné ovce, které nejsou z tohoto ovčince. I ty musím přivést. Uslyší můj hlas a bude jedno stádo a jeden pastýř.

\section{Jd.20,21}

Vy, milovaní, budujte svůj život na přesvaté víre, modlete se $v$ Duchu svatém, uchovejte se v lásce Boží a očekávejte milosrdenství našeho Pána Ježíše Krista k věčnému životu.

\section{Otče náš,}

s úctou a úžasem se díváme na Tvé dílo, od velkolepého vesmíru až k tajemnému mikrosvětu s jeho zákonitostmi, které se zcela vymykají naší představivosti. Myslíme při tom na zázrak života a na dar lásky. Vděčně si připomínáme, že to vše se nás bytostně týká.

V pokání si uvědomujeme svůj hř́ch, svůj podíl na porušení harmonie ve Tvém díle. Děkujeme za Pána Ježíše Krista, který ze světa sňal tíhu lidského hříchu i s jeho důsledky. Děkujeme Ti za pozvání na Jeho cestu, a prosíme Tě, aby toto pozvání zaznívalo do celého světa.

Prosíme Tě, ved'nás křestany, abychom byli dobrými a věrohodnými svědky o Tvé lásce. Prosíme Tě o požehnání pro Tvou církev, pro její práci, pro její shromáždění. Očekáváme, Otče, na Tebe. Amen.

Četli jsme známý text ze 17. kapitoly Skutků o Pavlově kázání v Aténách. Můžeme se setkat $\mathrm{s}$ jeho diametrálně rozdílnými výklady. Bývá zpravidla považován za ukázku toho, jak se při kázání má postupovat, ovšem setkal jsem se i s názorem zcela opačným, tedy že jde o ukázku toho, jak se kázat nemá. Pavel navazuje na myšlení a kult místních obyvatel a snaží se odtud posluchače převést k Bohu - Otci J eží̌̌e Krista. Je zkušeným kazatelem a zde je nám představen jeho promyšlený postup, který je dokonce $v$ souladu $s$ dnešními didaktickými představami. A tak je celkem přirozené vděčně přijmout skutečnost, že autor Skutků evangelista Lukáš nám zde zaznamenal, jak Pavel kázal. Je pravda, že těch, kdo se při této př́ležitosti obrátili ke Kristu, bylo relativně málo. Někdo $v$ tom může vidět i určité kazatelské fiasko, a tedy tvrdit, že tento př́běh ukazuje, jak se kázat nemá. Rozhodně je zajímavé setkat se s takto diametrálně odlišnými výklady, nicméně onen negativně kritický má vážné slabiny. Biblicky utvářenému způsobu myšlení se př́čí jakékoli pomyšlení na efektivitu zvěstování či na fiasko při kázání. Na aténském Areopágu mezi posluchači byli ti, kteří se $\mathrm{k}$ Hospodinu obrátili, a víme, že každé obrácení je důvodem radosti v nebi. A třeba v srdcích 
některých začínala probíhat určitá nepozorovatelná změna. A tak jsem přesvědčen, že evangelista Lukáš nám informaci o Pavlově aténském kázání zaznamenal jako pozitivní vzor.

Jedna má studentka - buddhistka pocházející z Vietnamu - mi nedávno doporučila nesmírně zajímavou knihu vietnamského buddhistického mnicha Thiče (Thich) Nhata Nhana "Živý Buddha, živý Kristus". Přečetl jsem si ji s velkým zájmem, a i s velkým užitkem. Autor, jemuž je křestanství velmi blízké, ukazuje na množství styčných bodů mezi buddhismem a křestanstvím. Uvědomil jsem si, že někdy není úplně jednoduché vyzvednout specifika toho kterého náboženství. Apoštol Pavel chce posluchačům, pro něž bůh (s malým "b") je docela běžným pojmem, srozumitelně a nenásilně přibližit Hospodina, jediného a jedinečného Boha Stvořitele, toho, který seslal na svět Ježíše Krista - Spasitele a Ducha sv. - Posvětitele. V kázání říká: "Vždyt' je to On sám, který všemu dává život, dech i všechno ostatní. On stvořil z jednoho člověka všechno lidstvo, aby přebývalo na povrchu země, určil pevná roční údobí i hranice lidských sídel. Büh to učinil proto, aby ho lidé hledali, zda by se ho snad nějakým způsobem mohli dopátrat a tak ho nalézt, a přece není od nikoho z nás daleko. Nebot' $v$ něm žijeme, pohybujeme se, jsme" (Sk.17.25-28). Bůh, kterého Pavel zvěstuje, zaslouží ohromný údiv - jeho dílo je tak úžasné, universální a funkční. My [u nás v jarovském sboru] každou neděli na začátku bohoslužeb ve zpívané modlitbě opakujeme "Tvému divíme se dílu" - ale je to skutečně pravda? Vnímáme svět se vším, co je na něm, skutečně s údivem?

Opravdové poznávání světa k údivu vede. Čím více člověk o světě a jeho fungování ví, tím více se musí divit. Dnešní fyzika pracuje s několika univerzálními konstantami, jakými jsou např. rychlost světla ve vakuu či Newtonova gravitační konstanta. Někteří fyzikové počítali, jak by vypadal svět, kdyby se hodnoty těchto konstant jen o maličko lišily od těch skutečných, a dospěli $k$ závěru, že fungující svět a život na něm by pak nebyly možné. $Z$ hlediska současné vědecké metodologie je to náhoda, že tyto konstanty jsou takové, jaké jsou, ale kdo ty skutečnosti, které věda objevuje, plně vnímá, musí prožívat hluboký a náhodě na hony vzdálený obdiv. Uvědomuje si, že vysvětlení, proč tomu tak je, leží za hranicemi vědy a rozumových možností. Podobně může vypadat zamýšlení nad teorií velkého třesku, která se týká začátku našeho vesmíru. Proč se vše vyvíjelo tak, že mohl vzniknout život, a to i $v$ tak komplexní formě, jakou je život lidský? Odpověd' na toto "proč" zas přesahuje hranice vědy. Můžeme jen s vděčností a údivem přijmout to, že vývoj vesmíru umožnil vznik života a člověka, vznik prostředí, kde se může uskutečňovat láska jako nejvyšší hodnota.

Schopnost divit se patři k plně prožívanému lidství. My někdy sklouzáváme do jakési vyprahlé, zašedlé racionality, která lidství - tedy stvoření k Božímu obrazu - zplošt́uje či omezuje. Co rozumem nevysvětlíme, jako by nás nezajímalo. A přitom: co vlastně rozumem vysvětlujeme? Nepleteme si vysvětlení s popisem a hledáním souvislostí? Naprostou většinu toho, co je předmětem popisné astronomie, můžeme vysvětlit pomocí tři základních Newtonových pohybových zákonů a jeho gravitačního zákona. Jenže: Proč tyto zákony platí? Víme, že jejich platnost je součástí světa, v němž žijeme, tedy součástí Božího stvořitelského díla. A vděčně si můžeme uvědomit, že ve světě, kde tyto zákony platí, můžeme žít. Ono „proč" ovšem zůstává nezodpovězeno. 
Svět. Vesmír. Jsoucno. Úžasné komplexní Boží dílo, plné nejrozmanitějších vazeb a vztahů, přírodních zákonů a parametrů. Někdo může namítnout, že to zas tak úžasné není. Vždyt́ ve světě bují násilí, nenávist, terorismus atd.! A nejen násilí vůči lidem, ale také vưči př́rodě. Porušení do světa vnesl lidský hřích. Nerozumíme tomu, proč to Bůh dopustil. Není na nás všemu rozumět. Rozhodně na pozadí hříchu si můžeme uvědomit hodnotu dobra. $\mathrm{A}$ hřích nemá poslední slovo. S lidským hříchem Boží tvưrčí dílo nekončí. Bůh poslal na svět Svého jedinečného Syna, aby z něj tíhu hříchu sňal. Není to další důvod k údivu?

Bůh je stále při díle. Jeho vrcholem je spasení. A jestliže stojíme v údivu před stvořeným světem se všemi jeho zákony a parametry, at' už myslíme na fyzikální konstanty či třeba na koncentraci kyslíku $v$ atmosféře, která umožňuje oheň jak rozdělat, tak i uhasit (kyslíku je dost $\mathrm{k}$ tomu, aby jej šlo rozdělat, a jeho koncentrace není zas př́liš velká, takže jej Ize uhasit), ještě větší údiv zaslouží dar spasení, dar lásky - Boží lásky k lidem i celému světu i dar lásky mezi lidmi. Vědomí Boží velikosti a Jeho lásky osvobozuje od malomyslnosti a vede $\mathrm{k}$ naději: Jemu na světě stále záleží. Záleží mu na tom, jak myslíme, co děláme, o co usilujeme, záleží na našich modlitbách. Boží zájem o svět přesahuje možnosti našeho rozumu i našich představ. Proto jsme dostali i schopnost divit se, dívat se v úžasu. Znovu se vracím ke zmíněné knize Thiče Nhata Nhana. Myslím při tom na onu úžasnou rozmanitost v Bohem stvořeném světě, k níž patří také to, že i lidé, kteří Krista explicitně nevyznávají, mohou se ve svých nitrech dívat za hranice rozumem a smysly poznatelného světa, proživat svobodu k opravdové lásce, poznávat Boží vůli a promítat evangelium do svých životů. Myslím zároveň na slova našeho Pána a Spasitele: Mám i jiné ovce, které nejsou z tohoto ovčince. I ty musím přivést. Uslyší můj hlas a bude jedno stádo a jeden pastýř.(J.10.16)

Divíce se Božímu dílu mysleme na lidi kolem nás, pamatujme na to, že svět potřebuje evangelium a prosme o sílu a opravdovou lásku k druhým. Pán Ježíš ríká svým učedníkům, a tedy i nám křestáanům $\vee 21$. století: Vy jste sůl země. Vy jste světlo světa (Mt. 5.13,14). A stále platí ona úžasná, rozumem nepochopitelná slova, která píše evangelista Jan (3.16): Bůh tak miloval svět, že dal svého jediného Syna, aby kdo $v$ něho věří, nezahynul, ale měl život věčný. Amen

Děkujeme Ti, Otče náš, za to, že jsi na svět poslal Pána Ježíše Krista, že On přišel a obětoval se pro všechny lidi, nejen pro členy etablovaných církví. Děkujeme, že miluješ všechny lidi a prosíme Tě, aby se tyto úžasné skutečnosti zřetelně promítaly do zvěstování evangelia, do křestáanských kázání. Prosíme, aby se poselství o lásce šírilo celým světem. Myslíme při tom na nemocné, slabé, zarmoucené, osamělé, na ty, kdo jsou v těžkých životních situacích. Prosíme Tě za ty, na něž těžce dopadají důsledky lidského násilí či prírodních katastrof.

Prosíme Tě za náš stát. Prosíme Tě o moudrost a nesobeckost pro ty, kdo jsou na vedoucích funkcích od celostátní po lokální úroveň. Prosíme Tě, ved’ naše lidské uvažování tak, abychom si uvědomovali, že jdeme světem společně, že dobro pro druhé lidi je i naším dobrem. Amen 